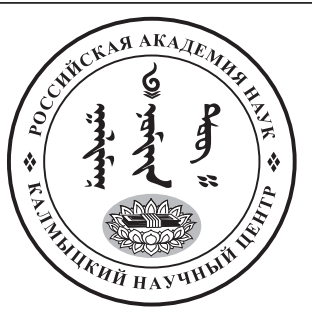

Published in the Russian Federation

Oriental Studies (Previous Name: Bulletin of the Kalmyk Institute

for Humanities of the Russian Academy of Sciences)

Has been issued as a journal since 2008

ISSN: 2619-0990; E-ISSN: 2619-1008

Vol. 13, Is. 3, pp. 779-789, 2020

DOI: $10.22162 / 2619-0990-2020-49-3-779-789$

Journal homepage: https://kigiran.elpub.ru

УДК 398.2:821.512.3

DOI: $10.22162 / 2619-0990-2020-49-3-779-789$

\title{
Мотив «богатырский поединок (сражение)» и его вариативный ряд в эпосах монгольских народов
}

\author{
Евдокия Эрендженовна Хабунова ${ }^{1}$, Людмила Санжибоевна Дампилова ${ }^{2}$, Алимаа \\ Аюушжавийин
}

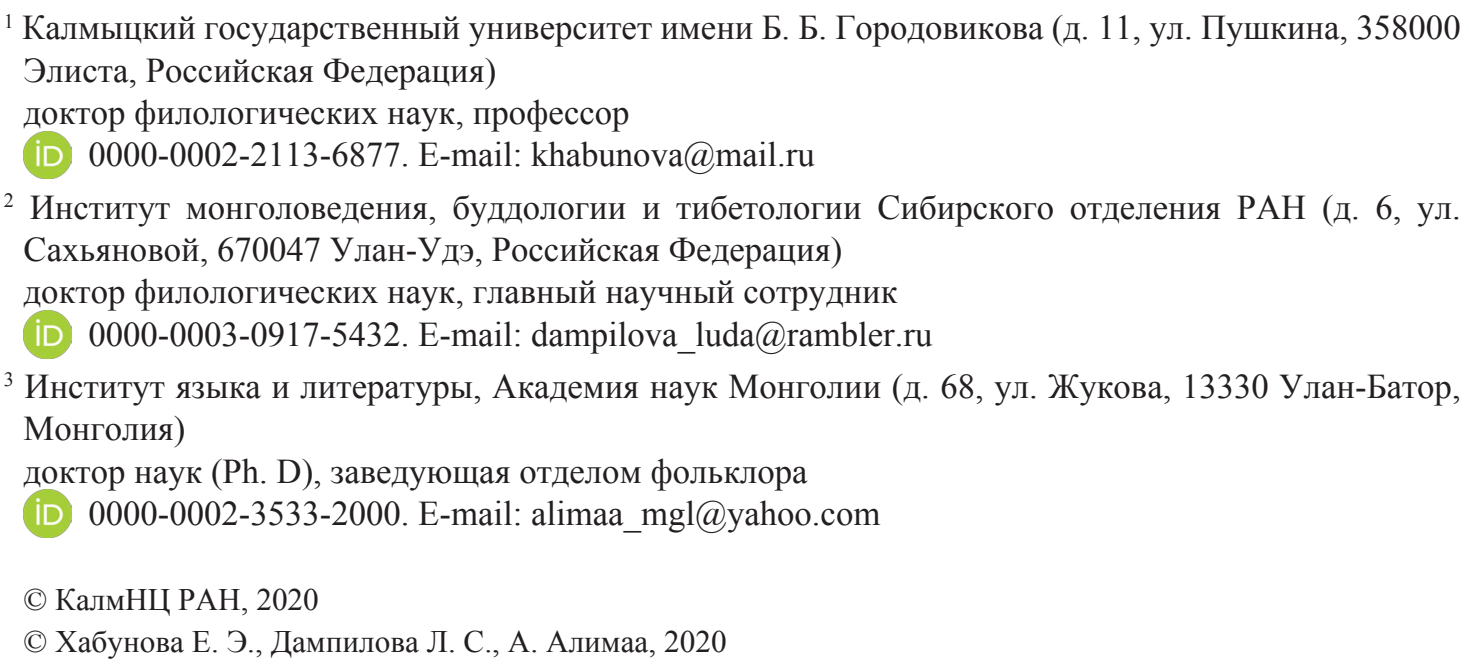

Аннотация. Введение. Актуальность исследования заключается в том, что в статье исследуется вариативное разнообразие мотива-инварианта «богатырский поединок (сражение)» как один из важных сегментов эпического сюжета, на основе сравнительного анализа ядерной основы мотива и его вариативного списка формируется структурно-содержательная модель мотива-инварианта эпоса монгольских народов, содержащего описание воинских коллизий. В таком аспекте данная проблема рассматривается впервые. Цель исследования - определить вариативное разнообразие мотива-инварианта «богатырский поединок (сражение)» в национальных эпосах бурят, калмыков, монголов, ойратов. Материалы. Вариативный ряд извлекается из эпосов монгольских народов: бурятские улигеры «Абай Гэсэр» (унгинский вариант П. Петрова), «Абай Гэсэр-хүбүүн» (эхирит-булагатский вариант М. Эмегенова), малодербетовский цикл и эпический цикл Ээлян Овла калмыцкого эпоса «Джангар», синьцзян-ойратская версия эпоса «Джангар», ойрат-монгольские туули «Дайни Кюрюль», «Хан Харангуй», халхаский тууль «Агийин Улан хаан». Методы исследования. Для выявления типологии и вариативных разночтений данного мотива в исследовании применяются элементы сравнительно-типологического, сравнительно-исторического методов. Мотивная модель «богатырский поединок (сражение)» рассматривается как элемент, который гипотетически может быть самым важным рычагом механизма сложения сюжета, эволюциони- 
руя от мотива — «простейшей повествовательной единицы» до сюжета и, наоборот, свертываясь от сюжета до мотива. При выделении мотива учитывается его дуалистическая природа, многообразие его свойств и признаков, отмеченных российскими и зарубежными учеными. Результаты. Сравнительное изучение мотива «богатырский поединок (сражение)» позволило выделить мотив как существенный конструктивный и содержательный элемент сюжета, увидеть степень продуктивности и мобильности мотива в генетически родственных, стадиально различных эпосах, а также в эпосах различных сказительских традиций, рассмотреть набор ситуаций, характерных для сюжета о богатырском противостоянии в эпосе монгольских народов. Bblводы. Исследование подводит к выводу, что мотивы-инварианты формируют сюжетную основу, а мотивы-варианты передают особенности (стадиальные, национальные, локальные) эпической традиции.

Ключевые слова: эпос, мотив, богатырский поединок, сражение, мотив-инвариант, вариант мотива, структурно-содержательная модель, монгольские народы

Благодарность. Исследование выполнено при финансовой поддержке гранта РФФИ в рамках научного проекта «18-512-94006 МОКНМ_а».

Для цитирования: Хабунова Е. Э., Дампилова Л. С., А. Алимаа. Мотив «богатырский поединок (сражение)» и его вариативный ряд в эпосах монгольских народов // Oriental Studies. 2020. Т. 13. № 3. C. 779-789. DOI: $10.22162 / 2619-0990-2020-49-3-779-789$

UDC 398.2:821.512.3

DOI: $10.22162 / 2619-0990-2020-49-3-779-789$

\title{
The Motif of Heroic Duel (Combat) and Its Variation Row in Mongolic Epic Traditions
}

\section{Evdokia E. Khabunova1, Ludmila S. Dampilova², Alimaa Ayuushzhaviyin ${ }^{3}$}

${ }^{1}$ Gorodovikov Kalmyk State University (11, Pushkin St., Elista 358000, Russian Federation)

Dr. Sc. (Philology), Professor

iD 0000-0002-2113-6877. E-mail: khabunova@mail.ru

${ }^{2}$ Institute for Mongolian, Buddhist and Tibetan Studies, Siberian Branch of the RAS (6, Sakhyanova St., Ulan-Ude 670047, Russian Federation)

Dr. Sc. (Philology), Chief Research Associate

iD 0000-0003-0917-5432. E-mail: dampilova_luda@rambler.ru

${ }^{3}$ Institute of Language and Literature, Mongolian Academy of Sciences (68, Zhukov St., Ulaanbaatar 13330, Mongolia)

PhD (Cultural Studies), Head of Folklore Department

iD 0000-0002-3533-2000. E-mail: alimaa_mgl@yahoo.com

(C) KalmSC RAS, 2020

(C) Khabunova Ye. E., Dampilova L. S., A. Alimaa, 2020

\begin{abstract}
Introduction. The article examines the motif of heroic duel (combat) as an important segment of the epic plot, and our comparative analysis of the nuclear basis of the motif and its variation list proves instrumental in delineating a structural-meaningful model motif invariant inherent to the epic of Mongolic peoples and depicting military conflicts. The issue has never been dealt with in this perspective. Goals. The work seeks to determine a variation row of the invariant motif in national epic traditions of Buryats, Kalmyks, Mongols, and Oirats. Materials. The variation row to be extracted from Mongolic epic narratives, namely: Buryat uligers of Abai Geser (Ungin version of P. Petrov) and Abai Geser Khubun (Ekhirit-Bulagat version of M. Emegenov), Baga Dorbet and Eelyan Ovla's cycles of the Kalmyk Epic of Jangar, Xinjiang Oirat version of the Jangar, Oirat Mongolian tuuli texts titled Daini Kyurel and Khan Kharangui, and a Khalkha tuuli titled Agiyin Ulan Khan. Methods.
\end{abstract}


To identify the typology and variable interpretations of the motif, the study uses elements of the comparative-typological and comparative-historical methods. The 'heroic duel (combat)' motif model is viewed as an element that hypothetically can act as the most important lever within the plot development mechanism, e.g., evolving from a motif — a 'simplest narrative unit' — to a plot, and vice versa. When it comes to identify the motif, its dualistic nature, variety of its properties and features noted by Russian and foreign scientists are taken into account. Results. The comparative insight into the motif of heroic duel (combat) makes it possible to single out the motif as an essential constructive and meaningful element of the plot, examine the degree of productivity and mobility of the motif in genetically related though stadially differing epics, as well as in ones belonging to various taletelling traditions, observe heroic confrontation patterns in epics of Mongolic peoples. Conclusions. The study concludes that motif invariants tend to form a plot basis, while motif variants express certain features (stadial, national, local) of each epic tradition.

Key words: epic, motif, heroic duel, battle, motif invariant, motif variant, structural-meaningful model, Mongolic peoples

Acknowledgements: The reported study was funded by RFBR, project no. 18-512-94006 MOKHM_a 'The Epic of Mongolic Peoples: An Annotated Catalogue of Traditional Motifs'.

For citation: Khabunova E. E., Dampilova L. S., A. Alimaa. The Motif of Heroic Duel (Combat) and Its Variation Row in Mongolic Epic Traditions. Oriental Studies. 2020. Vol. 13(3): 779-789. (In Russ.). DOI: 10.22162/2619-0990-2020-49-3-779-789

\section{है}

\section{Введение}

Описание боевых сражений и воинских доблестей представляет собой ключевой сегмент сюжета как героического эпоса монгольских народов, так и целого ряда мировых эпических традиций. Военные коллизии в эпосах изображаются по-разному как в содержательном плане, так и в структурном, текстовом воплощении, что находит отражение на мотивном уровне. Вполне возможно, что этот элемент является самым важным рычагом механизма сложения сюжета, эволюционируя от мотива - «простейшей повествовательной единицы» [Beселовский 1940: 500] до сюжета и, наоборот, свертываясь от сюжета до мотива.

Эпос монгольских народов - явление разностадиальное, это подтверждают образцы эпических повествований бурят, монголов, калмыков, синьцзянских ойратов, демонстрирующих различные варианты эволюционного развития устной эпической традиции и на уровне мотива. В этом контексте представляется актуальным выявление и сравнительное изучение вариативного разнообразия одного мотива — в данном случае мотива «богатырский поединок (сражение)», который в национальных эпосах монгольских народов находит разную структурно-содержательную манифестацию.
На основе анализа ряда эпосов о воинских коллизиях - бурятских улигерах «Абай Гэсэр» (унгинский вариант П. Петрова) [Абай Гэсэр 1960], «Абай Гэсэр-хүбүүн» (эхирит-булагатский вариант М. Эмегенова) [Абай Гэсэр-хүбүүн 1961], малодербетовского цикла и эпического цикла Ээлян Овла калмыцкого эпоса «Джангар» [Джангар 1999; Джангар 1990], синьцзян-ойратской версии эпоса «Джангар» [Джангар 2005], ойрат-монгольских туули «Дайни Кюрюль» [Дань хүрэл тууль 1986], «Хан Харангуй» [Хан Харангуйн тууль 2016], халхаского туули «Агийин Улан хаан» [Агийн Улаан хаан 1991]) - моделируется вариативный перечень мотива-инварианта «богатырский поединок (сражение)». В таком аспекте данная проблема рассматривается впервые.

\section{Методы исследования}

Оперируя понятием «мотив», прежде всего, мы берем во внимание его дуалистическую природу, выраженную через его структурно-содержательную самостоятельность. Учитывается также его «связь с событием», привязанность к формульным образованиям, к опорным словам, к предикату [Веселовский 1940; Пропп 2001; Дандес 2003; Мелетинский 1963; Неклюдов 1996; Путилов 1975; Силантьев 2002; Гацак 2000; и др.]. Такой подход, учитывающий 
многообразие свойств и признаков мотива, позволяет выделить мотив как существенный конструктивный и содержательный элемент сюжета в эпосах различной стадиальной формации, разных традиций (национальной, региональной, сказительской). Для выявления типологии и вариативных разночтений эпического мотива «богатырский поединок (сражение)», в исследовании применяются элементы сравнительно-типологического, сравнительно-исторического, структурного методов анализа [Пропп 2001; Путилов 1976; Мелетинский 1974; и др.].

Цель исследования - изучить мотив как существенный конструктивный и содержательный элемент эпического сюжета, определить характер вариативности мотива в генетически родственных, стадиально различных эпосах монгольских народов; определить структурно-содержательную модель мотива-инварианта «богатырский поединок (сражение)» на основе анализа его вариативных манифестаций в эпосах бурят, калмыков, ойрат-монголов, халха-монголов и синьцзянских ойратов.

Мотив-инвариант «богатырский поединок (сражение)» и его вариативный ряд в эпосе монгольских народов

Мотивы, характерные для общемонгольской эпической традиции, для героического эпоса в целом рассмотрены как мотивы-инварианты. В исследовании показано, как они моделируют основную канву сюжета эпических повествований: бурятских улигеров «Абай Гэсэр» (унгинский вариант П. Петрова) [Абай Гэсэр 1960], «Абай Гэсэр-хүбүүн» (эхирит-булагатский вариант М. Эмегенова) [Абай Гэсэр-хүбүүн 1961], малодербетовского цикла и эпического цикла Ээлян Овла калмыцкого эпоса «Джангар» [Джангар 1999; Джангар 1990], синьцзян-ойратской версии эпоса «Джангар» [Джангар 2005], ойрат-монгольских туули «Дайни Кюрюль» [Дань хүрэл тууль 1986], «Хан Харангуй» [Хан Харангуйн тууль 2016], халхаского туули «Агийин Улан хаан» [Агийн Улаан хаан 1991]).

Являясь «целостной» и относительно самостоятельной единицей сюжета, мотив обладает способностью к трансформации и перекодировке, что обеспечивает его вариативность. Отслеживание этих изменений в виде мотивов-вариантов может быть полезным для поиска и обнаружения инвариантного начала эпоса монгольских народов. Через призму мотивов-вариантов исследован набор ситуаций, характерных эпическому сюжету о богатырском поединке и сражении.

Варианты мотива «богатырский поединок (сражсение)» в калмыцком герочческом эпосе "Дюсангар"

В качестве отправного образца выбрана структура мотива «богатырский поединок (сражение)» главы «О Победе Алого Шовшура Славного над свирепым Шара Гюргеем, мангасовым ханом» калмыцкой версии героического эпоса «Джангар» [Джангар 1999], запечатлевшей древний пласт архаического эпоса, передающей картину эпических коллизий эпоса классической формации и во многом сохранившей «исконные, джунгарские черты, «несмотря на адаптацию в новой среде» [Кичиков 1997: 167].

Мотив-инвариант «поединок (сражение) богатыря (героя) с антагонистом, с врагами». Мотивы-варианты:

1. Сражался семь дней, отсекая головы врагов 50 полков, раз за разом выпуская стрелы [Джангар 1999: 180];

2. Сражался ещё три недели, отсекая головы врагов 80 полков, раз за разом выпуская стрелы [Джангар 1999: 180];

3. У богатыря возбудились семьсот тысяч отваг [Джангар 1999: 186];

4. Богатырь рубил самым длинным булатом сайдов и обычных, рубил лучников [Джангар 1999: 186];

5. Богатырь колет и нанизывает врагов на копье до упора и затем его выдергивает [Джангар 1999: 210];

6. Богатырь срубил 82 бархатных стяга врагов и отбросил назад [Джангар 1999: 186];

7. Богатырь разломал 82 бархатных знамени врагов, 42 их знамени разломал, 44 границы нарушил [Джангар 1999: 210];

8. Богатырь нанес мечом 61 удар по шишаку противника [Джангар 1999: 186];

9. Богатырю вонзились в ребра 8 тысяч крюков с одного бока и 6 тысяч - с другого бока, на темя обрушилось 6 тысяч острых мечей, в низ живота вонзилось 72 острия [Джангар 1999: 186];

10. Богатырь зашатался от 8 тысяч смертельных ран, светлый ум затуманился [Джангар 1999: 186]; 
11. Богатырь схватил противника мертвой хваткой, к небесам подбросил и на лету разрубил [Джангар 1999: 240];

12. Богатырь закрепил аркан из человеческих жил и с кличем «ура!» кинулся на врага [Джангар 1999: 240];

13. Богатыри рубились, утоляя жажду обильной черной кровью, свою белую кожу превратив в кольчугу-панцирь [Джангар 1999: 210];

14. Противник приковал богатыря к железной арбе стальной цепью толщиной в туловище человека и бросил восьми тысячам бесов [Джангар 1999: 186];

15. Восемь тысяч бесов ежедневно восемь тысяч раз пронзали богатыря каленым железом [Джангар 1999: 186, 220];

16. Богатырь разрубил бесовку надвое, нижняя ее часть вниз ушла, верхняя часть вверх поднялась [Джангар 1999: 186, 226];

17. Богатырь противнику справа пощечину влепил, правая щека его вздулась, слева пощечину влепил, левая щека пнем вздулась [Джангар 1999: 186, 230];

18. Богатырь нанес 72 удара своей тонкой белой голенью по его бокам, бросил на песок животом вниз, протащил и придавил, ударил мечом [Джангар 1999: 186; 230];

19. Богатыря уволокли вниз в жуткую багровую пропасть, бросили в седьмую преисподнюю свирепого красного моря на 72 года, подвергали каждый миг мукам дюжины адов [Джангар 1999: 186];

20. Богатырь мертвой хваткой схватил противника за щелоковый кушак, обрушил на землю с болтающимися вверху ногами, бил, пока скала в щебень не превратилась [Джангар 1999: 214];

21. Богатырь бил противника так, что четыре моря всколыхнулись, светлый ум затуманился, сандаловая голова закружилась [Джангар 1999: 214];

22. Богатырь бил, пока противник не растянулся до ста восьми саженей [Джангар 1999: 214];

23. Богатырь бросил противника на землю вниз животом, голову его вогнал в землю на семь локтей [Джангар 1999: 216];

24. Богатырь схватил, кинул перед собой двадцать миллионов раз, позади себя 10 миллионов раз кинул, прокатил лбом по земле четыре тысячи раз [Джангар 1999: 216];
25. Богатырь связал ступни раскоряченных ног противника на его спине, на уступ скалы положил [Джангар 1999: 216];

26. Богатырь схватил врага за запястье, ударил о землю миллион раз перед собой, ударил 100 тысяч раз, кинул, протащил его холмоподобным белым лбом по земле 4 тысячи раз [Джангар 1999: 230];

27. Богатырь вспорол ножом левый и правый бока бесенка, сердце с предсердьем разорвал [Джангар 1999: 230];

Приведенный перечень демонстрирует достаточно широкий диапазон вариативности мотива-инварианта «богатырское сражение». Его присутствие в эпическом сюжете эпоса «Джангар» (Малодербетовский список, 1864 г.) [Джангар 1999] обеспечило возникновение 27 вариантов, которые в разной вербальной сочетаемости появляются и в других нарративах. Это подтверждает закономерность их определения как мотивов-вариантов, обеспечивающих подвижность и продуктивность мотива-инварианта. Мотив-инвариант может быть более или менее разнообразен, но он всегда присутствует в сюжете, и его вариативность делает сюжет неповторимым, отличным от других.

Так, в главе калмыцкой версии «Джангара» из репертуара сказителя Ээлян Овла «О победе Алого Хонгора над Мангна-ханом и подчинение его Джангару» (1908 г.) поединок двух богатырей проиллюстрирован девятью вариантами мотива.

1. Богатырь ударил противника сзади бердышем так, что 72 застежки разлетелись и острие бердыша вонзилось в мышцы [Джангар 1990: 72];

2. Богатырь ударил врага, придавил к луке седла, крепко связал и швырнул на вершину горы [Джангар 1990: 72];

3. Богатырь связал и бросил на вершину горы 42 вражеских богатыря за три месяца [Джангар 1990: 73];

4. Богатырь ударил противника по лбу бердышем так, что искры посыпались, что от лезвия отломился кусок [Джангар 1990: 74];

5. Богатырь выстрелил вслед из лука величиной с дверной косяк, стрела вонзилась в аорту противника [Джангар 1990: 74];

6. Богатырь ударил бердышем так, что огонь взметнулся в небо, и 12 лезвий разлетелись на куски [Джангар 1990: 75]; 
7. Богатырь ударил врага бердышем по шейным позвонкам, раздробил врагу лопатки [Джангар 1990: 75];

8. Богатырь поднял врага на золоченое желто-пестрое копье, он дернулся, и копье разломалось на 12 частей [Джангар 1990: 76];

9. Богатырь закричал так, что земля содрогнулась, лопнул желчный пузырь у барca, лежащего в степи [Джангар 1990: 76];

Мотивный ряд эпоса «Джангар» варианта Ээлян Овла (1908) показывает, что сказитель детально обрисовал лишь один вид богатырского поединка с применением трех разновидностей оружия: в ближнем бою используется бердыш, на расстоянии - стрела, на исходе - копье.

В более раннем Малодербетовском цикле «Джангара» (1864) неизвестный джангарчи передал атмосферу длительного и многоэтапного противостояния богатыря разным противникам (полчища врагов, богатыри, сайды, лучники хана-антагониста, бесовка, бесенок) [Джангар 1999: 166-244].

Изображение поединка отличается детализацией всех условий сражения: продолжительность битвы, количество и статус противника, физическое и моральное состояние сражающихся, виды оружия, способы и результат его применения (подбросил вверх) и разрубил на лету; жажду утоляя кровью, пока кожа не превратилась в кольчугу, бил, пока скалы не превратились в щебень (мелкие камни); бил, пока враг не растянулся в 108 саженей; ударил миллион раз перед собой, сто тысяч раз кинул, четыре тысячи раз по земле протащил лицом вниз; вспорол бока, вынул и разорвал сердце и т. д.).

Такая конкретизация самого процесса поединка и физической расправы богатыря с врагом передает в большей степени стремление богатыря искоренить зло в лице противника, нежели демонстрацию его воинской доблести, как в эпосе более поздней фиксации.

Мотив «богатырский поединок (сражсение)» в синьцзян-ойратской версии "Джсангара"

Выстраивание вариативной модели эпических мотивов высвечивает особенности как различных локальных (сказительских) традиций, так и национальных версий одного и того же эпического произведения. К примеру, структурно-содержательная модель и тематическое разнообразие мотива «богатырское сражение» в главе «О том, как богатырь Алый Хонгор Львиноподобный покорил трех братьев-мангасов» синьцзян-ойратской версии эпоса «Джангар» ограничено 13 вариантами, среди которых следует обратить внимание на мотивы, характерные для сказочной традиции: боевой конь подсказывает Хонгору: когда достигнем границ владений мангасов, налетят беркуты Харчин и Барчин; с двух сторон набросятся собаки Хасыр и Басыр; далее находится жена черного Мангаса с трехмесячным ребенком в утробе, если его не уничтожить, не сносить нам головы; в северной стороне владений Мангаса живут два богатыря: Кюнде Хара и Догшин Хара [Джангар 2005: 265]; богатырь Хонгор прибывает в страну Мангасов, уничтожает беркутов Харчин и Барчин из лука с расстояния видимости [Джангар 2005: 267-268]; богатырь Хонгор своей граненой черной плетью разбивает лбы собакам Хасыр и Басыр так, что глаза повылетали из глазниц, а туши их разбросал, сделав из них приманки для ловли зверей [Джангар 2005: 268]; богатырь Хонгор рассекает тело ханши Шигтин Улан, из чрева которой выпадает мальчик с тянувшейся за ним пуповиной [Джангар 2005: 269].

Мотивы-варианты, выявленные из эпического нарратива, позволяют увидеть одну из особенностей синьцзян-ойратской эпической традиции - пестроту персонажного состава противников богатыря: мангасы, собаки Хасыр и Басыр, жена мангаса, ребенок мангаса, беркуты.

Вариативная модель мотива «богатырский поединок (сражение)» в бурятских улигерах

Сопоставление различных моделей мотива «богатырский поединок (сражение)» позволяет определить характер варьирования одного мотива не только в разных эпических, локальных, но и сказительских традициях. Обратимся к анализу различных вариантов бурятского улигера «Абай Гэсэр» (унгинский вариант П. Петрова) и «Абай Гэсэр-хүбүүн» (эхирит-булагатский вариант М. Эмегенова).

Вариативный перечень унгинского варианта эпоса «Абай Гэсэр» сказителя П. Петрова демонстрирует достаточно высокую амплитуду варьирования мотива «богатырский поединок» (30): 
1. Если взвалить на верблюда, они одинаковы, если бросить на коня - они равны [Абай Гэсэр 1960: 35-36];

2. Когда поскакал Абай Гэсэр хан, то громко крикнул - крики восьмидесяти драконов соединил [Абай Гэсэр 1960: 80];

3. Абай Гэсэр хан, не сворачивая, рысью влетел вместе с вещим гнедым конем в пасть чудовища [Абай Гэсэр 1960: 80];

4. Абай Гэсэр хан взял свое острое черное копье, которое в битве кровавой на тысячу саженей растягивается, Орголи белого чудовища пасть поперек подперев, дальше вошел [Абай Гэсэр 1960: 80];

5. Буйдэ Улан батор разрубил из подмышечных восемнадцати прожилок чудовища самую жизненную прожилку [Абай Гэсэр 1960: 80];

6. Абай Гэсэр хан, взяв копье, с тридцатью тремя баторами, на вещем гнедом коне на него скачет издалека, из двадцати семи голов змея самую жизненную голову насквозь протыкает [Абай Гэсэр 1960: 85];

7. Громадный змей, развернув тридцать три хвоста, ударяет Абай Гэсэра [Абай Гэсэр 1960: 85];

8. С каждым ударом огромный змей все больше слабеет [Абай Гэсэр 1960: 85];

9. Лучиночная стрела в зрачок правого глаза Абарга Сэсэн мангадхая занозой воткнулась, исчезла [Абай Гэсэр 1960: 108];

10. Одной стрелой тысячу воинов сразив, тысячу коней пригнал [Абай Гэсэр 1960: 119];

11. Все девять сражались, девять стрел выпустили, девять тысяч воинов сразили, девять тысяч коней пригнали [Абай Гэсэр 1960: 121];

12. Гал Дулмэ хан вскочил и желтым булатным кортиком перерубил Абай Гэсэр хана от правой ключицы до левой пятки самое сердце пронзил [Абай Гэсэр 1960: 186];

13. Абай Гэсэр хан, словно белый камень, звонко соединился, словно черный камень, крепко соединился [Абай Гэсэр 1960: 186];

14. Желтым булатным кортиком перерубил Гал Дулмэ хана от правой ключицы до левой пятки - самое сердце пронзил [Абай Гэсэр 1960: 186];

15. Гал Дулмэ хан, словно белый камень, звонко соединился, словно черный камень, крепко соединился [Абай Гэсэр 1960: 186];
16. Из костей выросли горы, из крови ручьи потекли [Абай Гэсэр 1960: 187];

17. Абай Гэсэр хан с Гал Дулмэ ханом снова схватились. Гал Дулмэ хан стал тянуть и тянуть - вот-вот под колени согнет [Абай Гэсэр 1960: 189];

18. Желтый булатный кортик Абай Гэсэр хана, воинов Гал Дулмэ хана начисто истребив, в ножны вернулся [Абай Гэсэр 1960: 189];

19. Тридцать три его батора в зеркально-стеклянной ограде закрыты [Абай Гэсэр 1960: 191];

20. Стрела Заса Мэргэна вонзилась и скрылась в зрачке заглавного белого глаза из наспинных ста тысяч глаз Гал Дулмэ хана [Абай Гэсэр 1960: 192];

21. Хангайскую черную стрелу приложил к тетиве славного желтого лука, стал натягивать свой лук до головки стрелы и пустил стрелу в семимесячного малыша [Абай Гэсэр 1960: 197];

22. Мясо его со спины десятью пальцами раздирал, мясо его с груди острием оружия перерезал [Абай Гэсэр 1960: 238];

24. Головы прострелили, тела разрубили, языки вырезали [Абай Гэсэр 1960: 238];

25. Могучая (хангайская) черная стрела в дьявола с чугунным кнутом попала, но, не пробив, отскочила [Абай Гэсэр 1960: 250];

26. Карающее черное копье в дьявола с чугунным кнутом метнул. Карающее черное копье, не пробив, соскользнуло [Абай Гэсэр 1960: 250];

27. Дьявол с чугунным кнутом стал чугунным кнутом стегать [Абай Гэсэр 1960: 250];

28. Абай Гэсэр хан его за обе руки поймал и схватил [Абай Гэсэр 1960: 250];

29 Абай Гэсэр хан желтый булатный кортик берет и рубит, но дьявола с чугунным кнутом не может разрубить [Абай Гэсэр 1960: 250-251];

30. Шерстобитным прутом Манзан Гурмэ бабушки стал бить и стегать [дьявола] [Абай Гэсэр 1960: 250-259].

Составление реестра мотивов-вариантов «богатырский поединок (сражение)» улигера «Абай Гэсэр-хүбүүн» (эхирит-булагатский вариант М. Эмегенова) показало меньшее количество вариантов - их оказалось 11 [Абай Гэсэр-хүбүүн 1961].

Как и в случае с калмыцкой традицией «Джангара», модель мотива «богатырский 
поединок (сражение)» и в этом случае высвечивает локальные (сказительские) различия одного и того же эпоса. В унгинском варианте бурятского улигера «Абай Гэсэр-хүбүүн» П. Петрова она передает накал, продолжительность поединка богатыря-воина с разного рода противниками (чудовище, дракон, змея, хан-антагонист) с использованием различных видов оружия (копье, стрела, кортик, кнут, шерстобитный прут). В эхирит-булагатском варианте этого же улигера сказитель М. Эмегенов посредством мотивов-вариантов показывает тонкости поединка богатырей-силачей, одного из трех видов мужских состязаний, изображаемых часто в сказочном фольклоре, в архаическом эпосе монгольских и других народов: сразимся мы мощью плеча? Иль сразимся мы силою пальцев больших, остротой наших стрел, быстротой коней? [Абай Гэсэр-хүбүүн 1961: 1, 156]; подобно изюбрям, друг друга подбрасывали, и, подобно быкам, они бились, бодаясь [Абай Гэсэр-хүбүүн 1961: 1, 57]; на месте, где бились, такая клубилась пыль, что как будто топтались, лягались стада [Абай Гэсэр-хүбүүн 1961: 1, 170]; подбирались друг к другу, и правой рукою, схватившись за шеи, стали дергать друг друга [Абай Гэсэр-хүбүүн 1961: 1, 41]; со спины (мангадхая Гэсэр) всеми пальцами сильных (рук) вырывал его мясо, бросал, а зубами передними белыми мясо грудной стороны вырывал и бросал [Абай Гэсэр-хүбүүн 1961: 1, 57-58]; его кровь он бурливым ручьем проливал, его мясо громадным холмом громоздил [Абай Гэсэр-хүбүүн 1961: 1, 57-58]; из легких старшего (того) мангадхая, из голых подмышек тянул его белые бронхи [Абай Гэсэр-хүбүүн 1961: 1, 57-58].

Реализация мотива «богатырский поединок (сражение)» в эпосе ойрат-монголов

Выборка мотивов-вариантов «богатырский поединок (сражение)» из монголо-ойратских эпосов «Дайни Кюрюль», «Хан Харангуй» дает основание полагать, что эти мотивы передают черты архаического эпоса, повествующего о борьбе богатыря в большей части с многоголовыми демоническими существами (мангасами, лусами), перечень видов оружия противоборства не отличается большим разнообразием: бо- гатырь Дайни Кюрюл, увидев посланника восьми лусов, выпускает в него грозные и стремительные стрелы, вобравшие в себя тысячу сил [Дань хүрэл тууль 1986: 50-51]; выпускает заговоренную стрелу в сторону дымового отверстия жилища противника [Дань хүрэл тууль 1986: 50-51]; богатырь советует четырем братьям не попасть под стрелы, отступить в безвыходной ситуации, чтобы избежать поражения [Дань хүрэл тууль 1986: 52]; уничтожил семидесятиголового мангаса и его стотысячное войско, превратил их кости в трупную муку, кости коней превратил в гравий [Дань хүрэл тууль 1986: 52].

Вариативный ряд мотива-инварианта «богатырское сражение (поединок)» другого монголо-ойратского эпоса («Хан Харангуй») свидетельствует, что богатырь против своих врагов выступает вместе со своими братьями Хэргис Сайн Буйдар и Уладай Мэргэн. Причиной столкновений богатыря Хан Харангуя и его противников служит месть: тенгрии желают наказать богатыря за прошлые грехи, богатырь уничтожает своих врагов за убиенных братьев. В описании поединка часто упоминается использование богатырями и их противниками заговоренной стрелы: при поддержке богатырей Хэргис Сайн Буйдар и Уладай Мэргэн Хан Харангуй сражается десять суток, не утоляя ни жажды, ни голода, оставляя лишь незначительную часть из тьмы врагов [Хан Харангуйн тууль 2016: 71]; тенгрии мстят Хан Харангую за то, что он забрал невесту и убил после этого трех борцов, переломал ноги двум бесовкам-шулмускам Ягаан и Цагаан (в обличье двух скакунов) и лишил коней скорости тысячи ветров [Хан Харангуйн тууль 2016: 73]; тенгрии направили письмо-жалобу из трех частей Эрлик номин хану, хану Мангасов, хану шулмусов с обещанием, что победившему Хан Харангуя будут переданы правление страной и религия [Хан Харангуйн тууль 2016: 73]; Хан Харангуй со слезами прижал голову мертвого Уладай Мергена к своей груди и сказал (поклялся): если найдутся силы, убьем черного мангаса и на нем устроим наше ложе, если не хватит сил, половину (войска) уничтожим. Так он сказал и снова начал рубиться мечом [Хан Харангуйн тууль 2016: 74]. 


\section{Мотив «богатырский поединок (сра- жсение)» в халхаском эпосе}

При исследовании мотива-инварианта «богатырский поединок (сражение)» и его вариативного разнообразия в халхаском эпосе «Агийн Улан хаан» обнаруживаются мотивы-варианты, отмеченные нами в других эпосах монгольских народов (богатыри встречаются на рубежной горе ранним утром; выбирают способ поединка; поочередно выпускают друг в друга стрелы, богатырь-протагонист разрывает жизненную аорту богатыря-антагониста и т. д.) [Агийн Улаан хаан 1991].

Вместе с тем в халхаском эпосе «Агийн Улан хаан» отмечен способ многократного протыкания противника в живот (брюхо мангаса), что не было замечено в вариативном ряде \мотива-инварианта «богатырский поединок (сражение)» в других эпосах.

Также многообразием отличается перечень животных, реагирующих на поединок богатыря с мангасом (верблюды, антилопы, рыси, олени, оленята, дзерен, кулан, сайга, беркут, косули-самки, косули-самцы, детеныши косулей, лисица, волк, змеи, ежи и даже сорока). Эти и другие отличия халхасского эпоса «Агийн Улан хаан» можно проследить в вариативном списке «богатырский поединок (сражение)»: встретились для единоборства на восходе солнца на горе Борзатын Бор толгой и бились, пока гора не превратилась в равнину, а равнина не стала подобна адской пропасти, безводное место заполнилось водой, а водное место осушилось [Агийн Улан хаан 1991: 27]; богатырь разорвал жизненную аорту мангаса, бросил так, что земля содрогнулась, проткнул его брюхо раз десять [Агийн Улан хаан 1991: 27]; весь

\section{Литература}

Абай Гэсэр 1960 - Абай Гэсэр. Сказитель П. Петров, зап. И. Н. Мадасона / вступ. ст., подг. текста, пер. и коммент. А. И. Уланова. Улан-Удэ: Бур. комплексный НИИ СО АН СССР, 1960. $314 \mathrm{c}$.

Абай Гэсэр-хүбүүн 1961 - Абай Гэсэр-хүбүүн 1961. Эпопея (эхирит-булагатский вариант) / подгот. текста, перев. и прим. М. П. Хомонова. Ч. І. Улан-Удэ: СО АН СССР; Бурят. комплекс. НИИ, 1961. 230 с.

Агийн Улаан хаан 1991 - Агийн Улаан хаан // Халх ардын тууль. Эмхэтгэсэн Р. Наран- животный мир (верблюды, антилопы, рыси, олени, оленята, дзерен, кулан, сайга, беркут, косули-самки, косули-самцы, детеныш косули, лисица, волк, змеи, ежи и даже сорока) вышел посмотреть на схватку богатыря и мангаса [Агийн Улан хаан 1991: 27].

Мотивный ряд также презентует поэтические формулы, характерные для устной традиции монгольских народов. «Формулы богатырского поединка могут быть показательны в плане изучения архаики» эпоса монгольских народов [Хабунова 2006: 121]. К примеру, метафорическая формула «силою плеч или крепостью больших пальцев» (борьба и стрельба из лука), «силой, полученной от родителей, или оружием, данным ханом» (единоборство или битва с применением оружия), передающая готовность противников ко всем видам богатырской схватки, встречается в разных интерпретациях во всех рассмотренных эпических нарративах.

\section{Заключение}

Мотивы-инварианты формируют сюжетную основу, а мотивы-варианты передают особенности (стадиальные, национальные, локальные) эпической традиции. Как правило, тематический состав мотивов-вариантов архаического эпоса менее разнообразен в плане изображения воинской доблести главного героя, чем в эпосе, сложившемся в более позднее время на фоне многочисленных героических событий, имевших место в истории монгольских народов.

Мотивы-варианты отражают специфику национального эпоса, передают особенности описания богатырских коллизий в эпосах калмыков, ойрат-монголов, халха-монголов, синьцзянских ойратов.

туяа, редактор: А. Лувсандэндэв, Ц. Дамдинсүрэн, П. Хорлоо (= Агийин Улан хан. Халхаский эпос. Сост. Р. Нарантуяа, ред.: А. Лувсандэндэв, Ц. Дамдинсүрэн, П. Хорлоо). Улаанбаатар: Улсын хэвлэлийн газар, 1991. Х. 25-29.

Веселовский $1940-$ Веселовский А. Н. Историческая поэтика / ред., вступ. ст. «Ист. поэтика А. Н. Веселовского»-и прим. В. М. Жирмунского; Ин-т лит. АН СССР. Л.: Гослитиздат, $1940.648 \mathrm{c}$.

Гацак 2000 - Гацак В. М. Фольклор - память традиции: уровни и формы этнопоэтической 
константности // Вестник Дагестанского научного центра РАН. 2000. № 8. С. 94-103.

Дандес 2003 - Дандес А. От этических единиц к эмическим в структурном изучении сказок / пер. с англ. А. В. Козьмина, коммент. А. В. Козьмина, А. С. Архиповой // Фольклор: семиотика и / или психоанализ: Сб. ст. / пер. с англ., сост. А. С. Архипова. М.: Вост. лит., 2003. С. 14-29.

Дань хүрэл тууль 1986 - Дань хүрэл тууль. Хэвлэлд бэлтгэсэн Б. Катуу. Ред. Х. Сампилдэндэв. Улаанбаатар: БНМАУ Ардын боловсролын яамны сурах бичиг, сэтгүулийн нэгдсэн редакцийн газар, 1986. 174 х. (= Эпос «Дайни кюрел». Подгот. к публ. Б. Катуу. Ред. Х. Сампильдэндэв. Улан-Батор: Объед. редакц. бюро учебников и журналов Мин. нар. образ. МНР, 1986. 174 с.).

Джангар 2005 - Джангар. Героический эпос синьцзянских ойрат-монголов. На калмыцком языке / в 3-х т. Т. 1. Элиста: АПП «Джангар», 2005. 856 с.

Джангар 1999 - Джангар. Малодербетовская версия. Свод. текст, перев., вступ. ст., коммент., словарь А. Ш. Кичикова. Элиста: АПП «Джангар». 1999. 270 с.

Джангар 1990 - Джангар. Калмыцкий героический эпос. На калм. и рус. яз. М.: Наука, 1990. 475 c.

Кичиков 1997 - Кичиков А. Ш. Героический эпос «Джангар». Сравнительно-типологическое исследование памятника. 3-е. изд. репр.. М.: Вост. лит., 1997. 319 с.

Мелетинский 1963 - Мелетинский Е. М. Происхождение героического эпоса. М.: Вост. лит., 1963. 459 с

Мелетинский 1974 - Мелетинский Е. М. Структурная типология и фольклор // Контекст:

\section{References}

Abai Geser Khubuun: Ekhirit-Bulagat Version. M. Khomonov (prep., transl., etc.). Vol. I. UlanUde: Buryat Comprehensive Research Institute (Sib. Branch, USSR Academy of Sciences), 1961. 230 p. (In Bur. and Russ.)

Abai Geser: Text Recorded from P. Petrov by I. Madason. A. Ulanov (foreword, prep., etc.). Ulan-Ude: Buryat Comprehensive Research Institute (Sib. Branch, USSR Academy of Sciences), 1960. 314 p. (In Bur. and Russ.)

Agiyn Ulaan Khaan. In: Narantuyaa R. (comp.), Luvsandendev A., Damdinsüren Ts., Khorloo P литературно-теоретические исследования. М.: ИМЛИ им. А. М. Горького АН СССР, 1974. С. 329-346.

Неклюдов 1996 - Неклюдов С. Ю. Варьирование как механизм фольклорной коммуникации // 100 лет Р. О. Якобсону: мат. межд. конгр. (г. Москва, 18-23 дек. 1996 г.). М.: РГГУ, 1996. С. 230-232.

Пропп 2001 - Пропn В. Я. Морфология волшебной сказки / науч. ред., текстол. коммент. И. В. Пешкова. М.: Лабиринт, 2001. 192 с.

Путилов 1975 - Путилов Б. Н. Мотив как сюжетообразующий элемент // Типологические исследования по фольклору. Сб. ст. памяти В. Я. Проппа / сост. Е. М. Мелетинский, С. Ю. Неклюдов. М.: Наука, 1975. C. 141-156.

Путилов 1976 - Путилов Б. Н. Методология сравнительно-исторического изучения фольклора. Л.: Наука, ЛО, 1976. 242 с.

Силантьев 2002 - Силантьев И. В. Теория мотива в отечественном литературоведении и фольклористике: очерк историографии. Науч. изд. Новосибирск: ИДМИ, 1999. 104 с.

Хабунова 2006 - Хабунова Е. Э. Героический эпос «Джангар»: поэтические константы богатырского жизненного цикла (сравнительное изучение национальных версий). Ростов н/Д: СК НЦ ВШ, ЮФУ, 2006. 256 с.

Хан Харангуйн тууль 2016 - Хан Харангуйн тууль. Удиртгал бичиж, үгийн тайлбар хийн орчин цагийн монгол хэлээр хөрвүүлж хэвэлд бэлдсэн Б. Түвшинтөгс (= Хан Харангуй эпос. Авт. предисл., коммент., перевода на совр. монг. яз. и подгот. к печати Б. Түвшинтёгс). Ред. И. В. Кульганек. Улаанбаатар; СПб.: Изд-во: Соёмбо принтинг, 2016. $209 \mathrm{x}$.

(eds.) Epic of the Khalkha (Mongols). Ulaanbaatar: People's Publ. House, 1991. Pp. 25-29. (In Mong.)

Daini Kyurel Tuuli. B. Katuu (prep.), Kh. Sampildendev (ed.). Ulaanbaatar: United Editorial Bureau of Textbooks and Journals (MPR's Ministry of Education), 1986. 174 p. (In Mong.)

Dundes A. From Etic to Emic Units in the Structural Study of Folktales. A. Kozmin (transl.), A. Arkhipova (comments). In: Arkhipova A. S. (comp.) Folklore: Semiotics and / or Psychoanalysis. Collected Papers. Moscow: 
Vostochnaya Literatura, 2003. Pp. 14-29. (In Russ.)

Gatsak V. M. Folklore - memory of the tradition: levels and forms of ethnopoetic constancy. Herald of the Daghestan Scientific Center. 2000. No. 8. Pp. 94-103. (In Russ.)

Jangar: Baga Dorbet Version. A. Kichikov (text, transl., etc.). Elista: Dzhangar, 1999. 270 p. (In Kalm. and Russ.)

Jangar: Heroic Epic of Kalmyks. Moscow: Nauka, 1990. 475 p. (In Kalm. and Russ.)

Jangar: Heroic Epic of Xinjiang Oirat Mongols. In 3 vols. Vol. 1. Elista: Dzhangar, 2005. 856 p. (In Kalm.)

Khabunova E. E. Heroic Epic of Jangar: Poetic Constants of a Hero's Life Cycle. A Comparative Study of Ethnic Versions. Rostovon-Don: North Caucasus Scientific Center for Universities (Southern Federal University), 2006. 256 p. (In Russ.)

Khan Kharangui Tuuli. B. Tüvshintögs (foreword, comments, translit., etc.). I. Kulganek (ed.). Ulaanbaatar; St. Petersburg: Soembo Printing, 2016. 209 p. (In Mong.)

Kichikov A. Sh. Heroic Epic of Jangar: A Comparative Typological Study. $3^{\text {rd }}$ ed. Reprint. Moscow: Vostochnaya Literatura, 1997. 319 p. (In Russ.)

Meletinsky E. M. Origins of Heroic Epic. Moscow: Vostochnaya Literatura, 1963. 459 p. (In Russ.)
Meletinsky E. M. Structural typology and folklore. In: The Context. Studies in Literary Theory. Moscow: Gorky Institute of World Literature (USSR Academy of Sciences), 1974. Pp. 329346. (In Russ.)

Neklyudov S. Yu. Variation as a form of folklore communication. In: Roman O. Jakobson. Celebrating the $100^{\text {th }}$ Anniversary of Birth. Congress Proceedings (Moscow; December 1823, 1996). Moscow: Russian State University for the Humanities, 1996. Pp. 230-232. (In Russ.)

Propp V. Ya. Morphology of Magic Folktale. I. Peshkov (ed., comments). Moscow: Labirint, 2001. 192 p. (In Russ.)

Putilov B. N. Comparative Historical Research of Folklore: Methodology. Leningrad: Nauka, 1976. 242 p. (In Russ.)

Putilov B. N. Motif as a plot forming element. In: Meletinsky E. M., Neklyudov S. Yu. (comps.) Commemorating Vladimir Ya. Propp. Collected Typological Studies in Folklore. Moscow: Nauka, 1975. Pp. 141-156. (In Russ.)

Silantiev I. V. Theory of Motif in Russian Literary and Folklore Studies: A Historiographic Essay. Novosibirsk: IDMI, 1999. 104 p. (In Russ.)

Veselovsky A. N. (ed.) Historical Poetics. A. Veselovsky (foreword), V. Zhirmunsky (comments). Leningrad: Goslitizdat, 1940. 648 p. (In Russ.) 